\title{
Elżbieta Skorupska-Raczyńska
}

Uniwersytet Szczeciński, Państwowa Wyższa Szkoła Zawodowa w Gorzowie Wlkp.

\section{Językowa kreacja matki w Nad Niemnem Elizy Orzeszkowej ${ }^{1}$}

\section{Wprowadzenie}

Funkcjonujący w polszczyźnie od XIV wieku wyraz matka ${ }^{2}$ w pierwotnym znaczeniu określał matkę ludzką (mater humana), a - upowszechniony w języku ogólnym - był w XIX wieku polisemem o osiemnastu jednostkach leksykalnych, przyporządkowanych znaczeniom prototypowym ('ta, co płód na świat wydała; kobieta jako rodzicielka') oraz wtórnym, powstałym w procesie generalizacji (np.: 'ksieni, przełożona klasztorna, przeorysza'; 'utrzymująca gospodę rzemieślniczą', czyli matka czeladna, gospodna; 'staruszka, kobieta poważna, babka; stara uboga; wieśniaczka na targu, gospodyni’; gw. 'żona') bądź metaforyzacji (np.: przyrodnicze 'roślina, z której się bierze sadzon-

${ }^{1}$ Wyniki dotychczas przeprowadzonych analiz języka powieści Nad Niemnem zamieściłam w następujących artykułach: Funkcja barw w językowej kreacji wybranych postaci $w$,Nad Niemnem” Elizy Orzeszkowej, w: Twórczość Elizy Orzeszkowej, red. K. Stępnik, Lublin 2001, s. 93-108; Barwy świata natury w „Nad Niemnem” Elizy Orzeszkowej, „Studia Językoznawcze” 2002, t. 1, s. 339-354; Kolorystyka dworu i zaścianka w „Nad Niemnem” Elizy Orzeszkowej, „Studia Językoznawcze” 2006, t. 5, s. 199-215; Językowa kreacja lasu w „Nad Niemnem” Elizy Orzeszkowej, „Zeszyty Naukowe PWSZ” 2006, z. 1, s. 137-146; Językowy obraz szlacheckiej XIX-wiecznej religijności w „Nad Niemnem” Elizy Orzeszkowej, w: Język doświadczenia religijnego, t. 3, red. G. Cyran, E. Skorupska-Raczyńska, Szczecin 2010, s. 145-164; Idiomy, frazemy, paremie w „,Nad Niemnem” Elizy Orzeszkowej, w: Ścieżkami pięknej polszczyzny, red. L. Mariak, A. Seniów, Szczecin 2011, s. 243-256.

${ }^{2}$ Według Andrzeja Bańkowskiego wyraz matka wyparł podstawowe staropolskie mać na fali szerzącego się w Polsce dość wcześnie kultu Najświętszej Maryi Panny, czyli Matki Bożej (por. A. Bańkowski, Etymologiczny słownik języka polskiego, t. 2, Warszawa 2000, s. 154). Jest to prawdopodobne, źródła bowiem wskazują, że pierwsze objawienia NMP, a tym samym przyporządkowane im miejsca kultu religijnego, datowane są na przełom X i XI wieku, o czym pisze P. Wadowski w pracy Obraz Matki Bożej w sanktuariach na ziemiach polskich (nieopublikowana praca magisterska, Szczecin-Paradyż 2011). 
ka'; 'główne koryto rzeki względem jej dopływów; stare koryto'; sportowe 'przewodniczący w grze w palanta, w gąskę, w zająca'; rzemieślnicze 'jedna z części składowych warsztatu stolarskiego'; anatomiczne 'jedna z błon mózgowych'; ‘żyła pośrodkowa ramienna'; bilardowe 'bila niebieska mająca najwięcej punktów'; hutnicze 'stempel wklęsły, forma wklęsła, w którą przy formowaniu wchodzi druga, wypukła, in. matryca'; zoologiczne 'królowa pszczół') $)^{3}$.

O statusie matki w kulturze polskiej świadczą liczne przysłowia, jak mówiące o jej niezastapionej roli w rodzinie, np.: Gdzie u dzieci matka, tam i główka gładka; Lepiej jak matka bije, niz jak macocha głaszcze; Droga to chatka, gdzie mieszka matka; ilustrujące bezmiar matczynej miłości, np.: Dziecię za ręke, matke za serce; Do ludzi po rozum, do matki po serce; Od matki dobre i ostatki; mądrości, np.: Dobra matka więcej nauczy niż stu nauczycieli; Matka dzieci jedna jagoda obdzieli; bądź trwałe prawa natury i obyczaju, np.: Jaka matka, taka córka; Jaka mać, taka nać; Jednej matki niejednakie dziatki ${ }^{4}$.

Obraz matki kreuje również literatura piękna. W standardowym wyborze lektur odnajdujemy zarówno ideały, jakim jest np. Podkomorzyna z Powrotu posła Juliana Ursyna Niemcewicza (patriotka, rozważna i mądra), matka Aliny i Balladyny (kochająca, czuła i troskliwa) czy Pani Stawska (matka Helenki z Lalki Bolesława Prusa); ale też negatywne typy, jak despotka i kołtunka Dulska, niedojrzała do macierzyństwa Emma Bovary, czy też kontrowersyjna Anna Karenina ${ }^{5}$.

\section{Kreacja matki w Nad Niemnem}

Zróżnicowany, a nawet skomplikowany wizerunek matki z drugiej połowy XIX wieku przynosi powieść Nad Niemnem Elizy Orzeszkowej ${ }^{6}$. Wnikliwa lektura utworu pozwala wyekscerpować z jego treści fragmenty ilustrujące kreację matki z tamtej rzeczywistości. Są to: matka Polka, matka kotka, matka kukułka, matka zaoczna i wierzbowa matka. Analizą dalej objęte zostały,

3 Por. Słownik języka polskiego, red. J. Karłowicz, A. Kryński, W. Niedźwiedzki, t. 1-8, Warszawa 1900-1927, zwany Stownikiem warszawskim (dalej: SW); tu: t. 2, s. 902-903.

4 Wybrane ze zbiorów: D. i W. Masłowscy, Przysłowia polskie, Katowice 2003; iidem, Przysłowia polskie i obce od A do Z, Warszawa 2003; SW 2, s. 902.

5 Por. B. Drabarek, J. Falkowski, I. Rowińska, Szkolny słownik motywów literackich, Warszawa 2004.

6 Korzystam z wydania w serii „Biblioteka Klasyki”: E. Orzeszkowa, Nad Niemnem, Wrocław 1996. Po cytacie podaję numer strony, z której pochodzi egemplifikujący fragment tekstu powieści. 
w kolejności: Maria Kirłowa, Andrzejowa Korczyńska, Starzyńska, Emilia i Marta ${ }^{7}$. Akcja powieści dzieje się w ciagu kilku miesięcy (od czerwca do września) 1886 roku, w nadniemeńskiej okolicy, zamieszkałej przez szlachtę dworską i zaściankową, stanowiącą plejadę barwnych postaci zarówno z jednej, jak drugiej strony.

Matka Polka. Obiegowo Matka Polka rozumiana jest jako 'symbol kobiety polskiej - matki, strażniczki ogniska domowego i patriotki's. Korzenie mitu Matki Polki, bohaterskiej kobiety dźwigającej każdy ciężar, sięgają okresu utraty przez Polskę niepodległości, kiedy kobiety Polki stanęły przed wieloma różnymi zadaniami, wśród których najważniejsze było wychowanie dzieci w duchu patriotyzmu i odpowiedzialności za pamięć przeszłości i za przyszłość nie tyle własna, ile innych. Jest to - jak podkreśla Izabela Kowalczyk - stylistycznie ,jednak przede wszystkim figura, konstrukcja stworzona na użytek historii, pomnikowa postać poświęcająca siebie i swe dzieci dla dobra ojczyzny. [...] to pewien ideał, ale również wzorzec określonej postawy dla ówczesnych kobiet" " W sytuacji nieobecności ojców, mężów, braci kobiety odpowiadały za dom, rodzinę i majątek. ,To kobiety zajmowały się prowadzeniem gospodarstw bądź interesów i wywiązywały się ze wszystkich tych ról nad wyraz dobrze"10.

W Nad Niemnem matką o konstrukcji usytuowanej najbliżej wizerunku Matki Polki jest Maria Kirłowa, żona wiszącego u pańskiej klamki próżniaka i pieczeniarza Bolesława Kirły, samotnie, ale z sukcesem prowadząca gospodarstwo i z pełnym oddaniem wychowująca pięcioro dzieci. Jej domeną jest przede wszystkim codzienna ciężka praca - dla dzieci.

Po sieni, kuchni i izbie czeladnej krzatała się Kirłowa. Dla chłodu i panujących w domu ciągów miała na sobie rodzaj sukiennego tułubka ${ }^{11}$, spod którego widać było tylko brzeg perkalowej ${ }^{12}$ spódnicy. To nawet gospodarskie, grube ubranie uczy-

${ }^{7}$ W powieści mówi się też o matkach wiejskich, które noszą niemowlęta u piersi w chustach; o matce Benedykta, której od dawna już nie miał; o nieżyjącej, nieszczęśliwej matce Justyny, we wspomnieniach zapisanej jako ta, która często i gorzko płakała; a także o matce Różyca, bardzo zacnej matronie, która w Rzymie siedzi na dewocji.

${ }^{8}$ Uniwersalny stownik języka polskiego, red. S. Dubisz, t. 1-4, Warszawa 2003 (dalej: USJP); tu: t. 2, s. 586.

${ }^{9}$ I. Kowalczyk, Matka-Polka kontra supermatka?, „Czas Kultury” 2003, nr 5 (113), s. 11.

${ }_{10}$ B. Budrowska, Macierzyństwo jako punkt zwrotny w życiu kobiety, Wrocław 2000, s. 193.

${ }^{11}$ Tulubek to - zgodnie z definicją zawartą w Stowniku wileńskim - 'kaftanik watowany'. Tam też kwalifikowany jako wyraz prowincjonalny. Por. Stownik języka polskiego, wyd. staraniem i pracą M. Orgelbranda, t. 1-2, Wilno 1861 (dalej: SWil); tu: t. 2, s. 1708.

12 Perkal jest nazwą gatunku cienkiego bawełnianego płócienka. Por. SWil 2, s. 986. 
nić jej nie mogło grubą i niezgrabną. Ze swą kibicią prostą, wysmukłą, o wdzięcznej linii biustu i ramion, która nadawała jej z daleka pozór pierwszej młodości, z ogorzałą cerą twarzy, silnie odbijającą od zawiązanej na szyi białej chustki, ze ślicznym warkoczem jasnych włosów niedbale z tyłu głowy skręconym - zagladała ona do dzieży $y^{13}$, w której dziewczyna miesiła żytnie ciasto, albo przechodząc do izby czeladnej nagladała prania bielizny, albo od płonącego w wielkim piecu ognia odstawiała hładysze $e^{14}$, w których mleko zsiadłe zamieniało się już w twaróg, i zastępowała je coraz innymi, które z ganku przynosiła. (233-234)

Ubrana wygodnie w watowany kaftanik i domową płócienną spódnicę krząta się i pomaga przy trzech jednocześnie odbywających się pracach (pranie, pieczenie chleba i robienie serów), co sama uznaje za ,błąd i złe rozporządzenie się gospodarskie" (234). Zestawienie prozaicznych czynności gospodarczych z prezentacją subtelnego mimo wszystko wyglądu zapracowanej kobiety służy jej gloryfikacji i podkreśleniu pełnionej funkcji - nie tylko gospodyni, matki, ale i pełnej wigoru i radości życia westalki domowego ogniska.

Kirłowa jest troskliwa wobec wszystkich swoich dzieci, zarówno najmłodszej Broni, która nie odstępowała matki, jak i starszych, już samodzielnych. Nie zostawia ich bez dozoru nawet na czas niedługi, jakim byłby np. wyjazd do najbliższych sąsiadów, Korczyńskich. Pojawiwszy się tam ze starszymi dziećmi, wyjaśnia zebranym i gospodyni domu swe spóźnienie:

- A jakże ja, moja pani, mogę tak w każdej chwili zostawiać w domu dzieci? Troje starszych odważyłam się wziać z soba, bo myślałam, że mi państwo tego za złe nie weźmiecie; ale dwoje młodszych nie mogłam przecież na rękach sług zostawić i musiałam czekać przyjścia Maksymowej, która je wyniańczyła i taką jest poczciwą babą, że byle tylko posłać po nią, zaraz przychodzi... Z małymi dziećmi to jak ze szkłem ostrożności trzeba... ale moja babula Maksymowa dobrze ich tam dopilnuje. (126)

Inicjującym wypowiedź pytaniem retorycznym kobieta nie tylko podkreśla swe przekonanie dotyczące wypowiadanego sądu, ale też angażuje uwagę słuchaczy i odwołuje się do ich wyobraźni.

Lęk o dzieci wzrasta w obliczu ich choroby. Tak jest np. w wypadku Stasia, który ma słabe gardło i co roku na nie choruje. Ze szczególną troską matka obserwuje zaangażowanie najstarszej córki Maryni w przyjaźń z Witoldem Korczyńskim, który wyjątkową sympatią darzy ładną dziewczynę z Olszynki. To

${ }^{13}$ Dzieża 'naczynie do rozczyniania i mieszania mąki na chleb' (SW 1, s. 654), dziś przestarzałe (USJP 1, s. 772).

${ }^{14}$ Hładysz gw. 'garnek do mleka, naczynie gliniane bez ucha' (SW 2, s. 838). 
ich widząc razem, Kirłowa niepokoi się o przyszłość córki, która - jak kiedyś Justyna - mogłaby doświadczyć odtrącenia:

Z oddalenia, w jakim się znajdowała, Kirłowa słyszała tylko oderwane wyrazy: lud, kraj, gmina, inteligencja, inicjatywa, oświata, dobrobyt itd. Parę razy tylko do uszu jej doszły całe okresy żywcem jakby z mądrej jakiejś książki wyjęte, a prawiące coś o pracach podstawowych i minimalnych, o poprawianiu historycznych błędów itd. Uśmiechnęła się prawdziwie po macierzyńsku, trochę żartobliwie, a trochę dumnie. - Dobrze - rzekła - kiedy tak, to dobrze! Niech sobie gwarza o takich pięknych rzeczach! (269)

Te „piękne rzeczy” są odpryskiem pozytywistycznych poglądów głoszonych żarliwie przez młodego Korczyńskiego, ale też przekonań bliskich Kirłowej, która zgodnie z ówczesną tendencją nie zabiega o rozwój u swych dzieci narodowowyzwoleńczych i powstańczych instynktów, a raczej wychowuje je do służby narodowi pracą i przez pracę. Podstawą zaś wychowania patriotycznego jest według Kirłowej wykształcenie dzieci, do którego przywiązuje najwyższą wagę, o czym świadczy np. jej desperacka walka o status szkolny niegarnącego się do nauki syna. Kirłowa, walcząc o Bolesia, odrzuca zasady, a nawet własny honor, jest gotowa poświęcić dla dziecka wszystko:

Boleś zaś dwa lata już w drugiej klasie przesiedział i jeszcze promocji nie dostał. Zlękta się była tego ogromnie. Na rok trzeci w tej samej klasie pozostać nie wolno. Pójdzie precz ze szkoły i co ona z nim potem zrobi? Pojechała do miasta i wyprosiła, wychodziła, wyjęczała dla niego pozwolenie zdania powtórnych egzaminów po wakacjach. Powinien się więc do nich przygotowywać, a nie chce. Swawolny i leniwy. W ojca się wrodził. (237)

To jego Kirłowa konsekwentnie i rygorystycznie do nauki, mimo wakacji, przymusza, a nałożone obowiązki egzekwuje. Buntującego się i dezerterującego od zadań szkolnych chłopca matka traktuje z mądrą surowością, ale rozpaczą reaguje na każdą podejmowaną przez niego próbę ucieczki od książek. Po kolejnym z ,podobnych skandalów”, jakim były w Olszynce gonitwy za zbiegiem, Kirłowa posuwa się do niekonwencjonalnego rozwiązania:

Dziewka od dzieży zbiega dogoniła, który z pogardą eksportę ${ }^{15}$ jej łokciem odpychając, nadąsany, ale i zawstydzony, do domu wrócił. Kirłowa z rozpacza w oczach

${ }^{15}$ Eksporta lub eksportacja w polszczyźnie XIX wieku funkcjonowały obiegowo w znaczeniu 'wyprowadzenie ciała, pogrzeb' (SW 1, s. 682); dziś tylko eksportacja - jako rel. i urz. 'wyprowadzenie zwłok na miejsce, w którym pozostają do momentu pogrzebu' (USJP 1, s. 805). 
i gestach ze skrzyni stojącej w sieni i będącej składem przeróżnych rupieci gruby sznur dostała.

- Chodź! - z wielką powagą do syna rzekła i za rękę go wziąwszy do bawialnego pokoju wprowadziła drzwi za sobą zamykając. Słychać było, że mówiła tam z gniewem $i$ krzykiem, to znowu tonem upominania i przekonywania; wyszła po chwili z twarza w ogniu, z drżacymi trochę rękami i ustami. Widać było po niej, że to srogie mentorstwo, które zmuszoną była względem dzieci swych okazywać, wiele ją kosztowało. Drzwi na klucz już nie zamykała, a na wystraszone i pytające spojrzenie Rózi odpowiedziała: - Przywiqzałam go do kanapy i kazałam uczyć się... Mocno przywiqzałam... (237-238)

Wprowadzony do opisu termin eksporta, przyporządkowany funkcjonalnie przeżyciom o odmiennej treści, podsumowuje żartobliwie status chłopca, który poległ w walce, ale jednocześnie, kontrastując z opisem przeżyć matki, podkreśla jej desperację. Służą temu również zestawione w opisach szeregowo okoliczniki i przydawki.

Kirłowa, mimo krzątaniny, czuła wobec dzieci, jest konsekwentna, surowa (kiedy sytuacja tego wymaga), troskliwa i cierpliwa, szczególnie wobec najmłodszej Broni, wymagającej permanentnej opieki, co odzwierciedla opis niezmiennego - wydaje się - obowiązku wiązania tasiemek u trzewiczków: „Kirłowa na ziemi przysiadła i spełniać zaczęła robotę Penelopy” (236). Porównanie kobiety i jej pracy do roboty mitycznej bohaterki sugeruje z jednej strony bezproduktywność czynności, która nie skończy się nigdy ${ }^{16}$, z drugiej wskazuje na bezgraniczne oddanie matki rodzinie, co ilustrują również słowa: „Zreszta, dla dzieci... wszystko...” (263).

Kirłową jako osobę wyjątkową postrzegała również Justyna, która okazywała tej kobiecie od zawsze wielki szacunek i takąż sympatię. Dostrzegała też w zacnej Kirłowej „żywe podobieństwo do swej wcześnie utraconej matki” (743). W wyrażeniu żywe podobieństwo zakodowane jest odniesienie do sytuacji życiowej obu matek: Kirłowej i Orzelskiej.

Matka kotka ${ }^{17}$. Typem romantycznej Matki Polki mogłaby być matka Zygmunta. Odnajdujemy ją w dożywotnim stanie wdowieństwa, połączoną do końca życia więzami pamięci z poległym mężem, powstańcem Andrzejem Korczyńskim. Jako altruistka poświęcała się ubogim, choć ,,Z nieprzezwyciężona odrazq spoglądała na [ich - E.S.R.] brudne ciała, niezgrabną odzież, odymione

\footnotetext{
${ }_{16}$ Praca Penelopy przenośnie oznacza czynność niekończącą się, bezproduktywną. Zob. W. Kopaliński, Stownik mitów i tradycji kultury, Warszawa 2001, s. 849.

${ }^{17}$ Syndrom matki kotki nie został dotychczas zdefiniowany naukowo. Dostrzega się go u kobiet, które na pierwszym miejscu stawiają interesy i potrzeby syna, często jedynaka lub jedynego chłopca wśród dzieci w najbliższej rodzinie, zapominając o własnych potrzebach i oczekiwaniach innych członków rodziny. Por. np. Rodzina i dziecko, red. M. Ziemska, Warszawa 1979.
} 
ściany, zgrubiałe i wykrzywione kształty i rysy" (480). Jako szlachetna dama, oddana wszystkim słabszym zajęła się również Justyną, osieroconą krewną:

Zajęła się, nawet szczerze i starannie. Na współkę z panem Benedyktem opłacała nauczycielki Justyny, Sprawiała jej coraz nowe i ładne suknie, sprowadzała dla niej ksiązki i nuty. Czasem dorosłą już dziewczynkę na tygodnie i miesiące zabierała do swoich niegdyś pięknych i obszernych [...] Osowiec. (149)

Była wymagająca wobec siebie i innych, ale nie w stosunku do Zygmunta. Zapatrzona w jedyne dziecko, traktowane od początku jak książątko, i zaślepiona bezgraniczną miłością do niego podejmuje nielicujące $\mathrm{z}$ wizerunkiem Matki Polki kroki, których skutki ranić będą nie tylko ją, ale i inne, związane z Zygmuntem osoby. Wyniosłość nie pozwala jej na proponowane przez Benedykta oddanie syna do szkół publicznych, ponieważ tam zmieszałby się „,z tłumem pełnym najpoziomszych, a może i najbiedniejszych instynktów, zwyczajów i pojęć” (491), ponieważ tam zaraziłby się ,pospolitościq, prostactwem, a może nawet panującą na świecie gonitwa za zyskiem, karierq, grubym materialnym użyciem ${ }^{18 "}$ (491). Jej duma nie dopuszcza myśli o małżeństwie Zygmunta z Justyna, ponieważ ,pragnęła dla syna kobiety wysoko urodzonej z rozległymi koligacjami, z wychowaniem świetnym, jakiejś na koniec muzy" (151). Zapatrzona w syna i zaślepiona miłością do niego, dostrzegając tylko to, co chciała w nim widzieć, budowała własny wizerunek genialnego, stworzonego do wyższych celów dziecka:

Zawsze i silnie przekonaną była, że w synu jej i Andrzeja prędzej lub później objawić się musi jakaś zdolność nad pospolity poziom go wynoszqca, jakaś niby iskra z krwi rodziców przez naturę wzięta i na jego czole w gwiazdę pierwszej wielkości rozniecona. W mniemaniu jej inaczej być nie mogło: syn jej $i$ Andrzeja człowiekiem pospolitym, takim, jacy sktadaja szare i bezimienne tlumy, być nie mógt. (499)

Długo oczekiwany sukces artystyczny Zygmunta - choć niewielki - przyniósł Korczyńskiej chwilę „prawie upajającego szczęścia” (501), spełniły się jej „najgorętsze pragnienia”, a o przyszłości syna myślała „prawie z ekstazą” (501). Modląc się, już nie skarżyła się, nie wylewała łez i skarg, a „o szczęściu i nadziejach swoich opowiadała duchowi Andrzeja” (502). Jak romantyczna matka Polka widziała w swym jedynaku geniusza, chlubę i światło narodu.

18 Grube materialne użycie rozumieć można jako ordynarne, proste, poziome i pospolite przyjemności, hulanki, rozkosze. Por. SW 7, s. 430. 
Będzie on, wspólnie z garstką wybranych, świattem roznieconym $w$ ciemności, chluba poniżonych, świadectwem życia pozornie umarłym. Jego natchnienia utworzą jedną z desek ratunkowego mostu nad przepaściami unicestwienia i zguby, wytworza jedna z cegieł do budowania arki, która płomień życia przenosi na drugą stronę gaszącej go powodzi. (501)

Przesycona zmetaforyzowanymi epitetami wizja wizerunku Zygmunta, który ma wraz z nielicznymi odradzać naród jak Noe ludzkość po potopie, pośrednio nawiązuje do Mickiewiczowskiego manifestu zawartego w apostrofie Do matki Polki ${ }^{19}$. Andrzejowa Korczyńska odrzuca jednak apel poety, buduje bowiem obraz syna mesjasza, a nie bojownika.

Korczyńska jest Zygmuntowi bezgranicznie oddana, co ten konsekwentnie wykorzystuje, wiedząc, że matka wszystko dla niego uczyni, jak wtedy, gdy na jego wezwanie pośpieszyła do ,rodziców Klotyldy i wahających się nieco skłoniła do powierzenia jej synowi siedemnastoletniego, pięknego, utalentowanego dziecka" (526). Po powrocie syna z zagranicy matka dostrzega i zło, jakim jej ukochany jedynak jest przesycony, i własne błędy wychowawcze. Jest rozczarowana, zrozpaczona, ma żal do siebie, co dostrzegają również jej sąsiedzi.

Wieści chodzą, że gospodarstwem prawie się nie zajmuje i interesy swe wcale nieosobliwie prowadzi, a pani Andrzejowa żałować już zaczyna, że wychowała syna w nadzwyczajnych pieszczotach, z dala od kraju i tego kawałka ziemi, na którym żyć mu wypadało. - Dobrze jej tak, bo jest dumna jak udzielna księżna i syna za półbożka miała... (115)

Andrzejowa Korczyńska jest altruistką i patriotką, postacią tragiczną, oddaną innym, a bez reszty Zygmuntowi, ma zatem znamiona Matki Polki, ale jej językowa kreacja bliska jest także w Nad Niemnem wizerunkowi matki kotki, która zapatrzona bezkrytycznie w swego wyidealizowanego poza granice rozsądku syna gotowa jest dla tego ideału zrobić wszystko.

Matka kukułka. W Nad Niemnem kobietą, która swe dzieci podrzuca na wychowanie, jest Starzyńska, matka Janka Bohatyrowicza i jego przyrodniej siostry Antolki Jaśmontówny. Dla kobiety, jak sama mówi, „największy walor maja: kochanie i dozgonny przyjaciel" (333). Ona to po śmierci Jerzego zostawia Janka pod opieką Anzelma w Bohatyrowiczach i wyprowadza się do Jaśmonta. Jedenaście lat później kolejny raz wychodzi za mąż, tym razem za Starzyńskiego ze Starzyn, wdowca z gromadką dzieci. Przedtem jednak sześcioletnią wówczas Antolkę oddaje Jankowi na wychowanie, ponieważ była ona w pewnym stopniu przeszkodą na drodze do jej szczęścia, co później tłumaczy Justynie:

\footnotetext{
19 A. Mickiewicz, Do matki Polki, w: Wybór poezji, t. 2, Wrocław 1986, s. 201-203.
} 
Ze Starzyńskim my jedne do drugiego chylili się jak dwa gołębie, ale wdowcem on był, gromadkę wielką w chacie miał, z przyczyny córki mnie nie chciał brać. „Bo to gdzie ja tam będę - powiada - do siedmiorga dzieci swoich jeszcze jedno cudze przyprowadzał!” [...] Wzięłam Antolkę $i$ do Janka ja przywiodtam: „Masz tobie, synku, siestrę. Hoduj ty ja, a ona tobie do pomocy stanie”. Jemu wtedy było lat dwadzieścia, a jej sześć. Anzelm był strasznie gniewny. (334)

Janek zajął się siostrą bardzo troskliwie, ,na rękach nosił, karmił i odziewał" (334), dowodząc swej dojrzałości i odpowiedzialności; wiedząc, że „u ojczyma mogłaby w poniewierce ostawać” (334). Anzelma rozgniewało postępowanie bratowej; decyzji kobiety nie akceptowali również sąsiedzi, dla których Starzyńska mająca dwoje dzieci żadnego z nich sama nie wyhodowała, ,jak kukawka ${ }^{20 "}$ (335).

Kukułce w kulturze europejskiej przypisuje się bogatą symbolikę, a o charakterze kukułki wypowiadał się już Arystoteles, który powołał się na powszechne wówczas opinie, mówiące, że nie buduje ona gniazda, ale podrzuciwszy swoje jaja innym ptakom, zżera te złożone wcześniej przez gospodarzy zajętego gniazda ${ }^{21}$. Jak podaje Piotr Kowalski, ,średniowiecze zrobiło z tego osobliwy użytek - «kukułkami» nazywano kobiety lekkich obyczajów"22. Kukułka, również ze względu na jej obyczaje, symbolizuje m.in. egoizm (pozwalający na podrzucanie innym swych dzieci na wychowanie), pasożytnictwo i oszustwo, małżeństwo i miłość, a także lubieżność oraz gadulstwo ${ }^{23}$. Cechy te mogą być społecznie przypisywane Starzyńskiej, którą Anzelm mimo wszystko szanuje, a po latach żartobliwie ocenia: ,gdyby dziś owdowiała, toby za rok poniosła się ${ }^{24}$ jeszcze za czwartego" (430).

Starzyńska mimo wszystko jednak była obecna w życiu swych dzieci, bo „choć płocha i w romansach niepowściagniona ${ }^{25}$, dzieci swoje często nawiedzała" (442), a i Anzelma, niedomagającego czasem, doglądała. Jest kobietą bardzo pracowita, świadomą swych wad i zalet: „Klepkują ${ }^{26}$ ze mnie ludzie,

${ }^{20}$ Wyraz kukawka w polszczyźnie XIX wieku był (obok kukułki, gżegżółki i zezuli) jednym z obiegowych określeń popularnego w naszej faunie ptaka z rodziny cuculus canorus. Równolegle funkcjonowały gwarowe: kukulka, kukuczka, gżegótka, zuzula i zozula. Por. SW 2, s. 623.

${ }^{21}$ Arystoteles, Zoologia, Warszawa 1982, s. 397.

${ }_{22}$ P. Kowalski, Leksykon. Znaki świata. Omen, przesad, znaczenie, Warszawa-Wrocław 1998, s. 273.

${ }^{23}$ Szerzej: W. Kopaliński, Stownik symboli, Warszawa 2001, s. 178-179.

${ }^{24}$ Ponieść się gw. 'pośpieszyć'. Za: J. Karłowicz, Stownik gwar polskich, t. 4, Kraków 1906-1911, s. 254.

${ }^{25}$ Niepowściagniony 'niepohamowany, nieumiarkowany'. Por. SW 4, s. 869.

${ }^{26}$ Klepkać gw. 'paplać, pleść, bezmyślnie co powtarzać, bezustanną gadaniną uprzykrzać się' (SW 2, s. 356). 
że kochliwa jestem [...]. Za toż o lenistwo nigdy na ludzkie języki nie padałam! I w swojej chacie wszystko zrobię, i synkowi na pomoc przybiegnę!" (347). Stara się jak najczęściej pomagać Jankowi w gospodarstwie, łącząc tę pracę z obowiązkami w Starzynach, szczególnie w czasie wzmożonych prac polowych, co jej dzieci doceniają:

Jan siostrę o matkę zapytał. Powiedziała mu, że do Starzyn poszła, do męża, a jutro raniutko powróci jeszcze na dni kilka, aby im żąc pomagać. W Starzynach grunta niskie, więc żniwa późniejsze, dlatego może ona przy żniwach dzieciom pomagać, a potem do swoich w pore doskoczyć. Dwie mile ujdzie dziś w jedną stronę, a dwie jutro z powrotem i z sierpem na polu stanie, jakby nie pięćdziesiąt, ale dwadzieścia lat miała. (425-426)

Rodzeństwo odczuwa jednak brak matki, z którą Antolka wychowywała się przez kilka lat, a Jan nigdy tak naprawdę nie był. Oboje wiedzą, że ich matce bliżsi pozostają mąż i jego dzieci, którzy - jak mówi dziewczyna - są jej „swoi”, czyli do niej należący ${ }^{27}$. W opozycji do swoich pozostają obcy, a taką z dużym prawdopodobieństwem jest dla Antolki jej matka, którą zastąpił dziewczynce brat. To o Janku ze wzruszeniem mówi, że „lepszego jak on to już prawie na całym świecie nie ma" i że przy nim ona „żadnego smętku [...] nie doznała" (335). Nie identyfikuje się z matką, która w dzieciach, dumna $\mathrm{z}$ nich, chce dostrzec jednak do siebie podobieństwo. Ilustruje to np. opinia Starzyńskiej o Janku, który - według matki - do niej się przyrodził² , bo „czuły i taki romansowny ${ }^{29} "$ (348).

Matka zaoczna. Zaocznym w polszczyźnie XIX wieku (i podobnie współcześnie) nazywano to, 'co dzieje się lub dokonuje w czasie nieobecności osoby zainteresowanej' ${ }^{30}$. Miano matki zaocznej w powieści możemy przypisać Emilii Korczyńskiej, skupionej na sobie i realizacji własnych potrzeb, rozegzaltowanej romantyczce żyjącej w świecie namiętnie pochłanianych przez nią powieści i powieścideł (w kreacji bliska jest ich bohaterkom).

Jakkolwiek skądinąd wyglądała na lat blisko czterdzieści, nie miała ani jednego siwego włosa, i jakkolwiek kibić jej i cera zdradzały do niedołęstwa posuniętą

${ }^{27} S w o i$ 'należący do kogo, będący z kim w jakimkolwiek związku'; swój w polszczyźnie XIX wieku to także 'swojak, rodak, współziomek', dziś potoczne. Por. SWil 2, s. 1604-1605; USJP 3, s. 1462.

${ }^{28}$ Przyrodzić się do kogo 'urodzić się podobnym do kogo, wrodzić się, wdać się w kogo'. W Stowniku warszawskim kwalifikowany jako wyraz dawny (SW 5, s. 356).

${ }^{29}$ Romansowny (człowiek) 'skłonny do romansów, kochliwy' (SW 5, s. 560).

${ }_{30}$ Por. SW 8, s. 197; USJP 4, s. 838. 
fizyczna słabość, drobne jej wargi były pasowe i świeże jak u młodziutkiej dziewczyny. Raczki drobne, tak chude i delikatne, że prawie przezroczyste, tak pielęgnowane, że paznokcie ich posiadały kolor listka róży i połysk politury. Z wyrazem niemocy lub słodkiej rezygnacji splatała je ona i opuszczała na suknię albo rozmawiając czyniła nimi gesta rzadkie, drobne, powolne, objawiające śmiertelną obawę przed wszelkim żywszym i choćby odrobinę energiczniejszym poruszeniem ciała czy ducha. (31-32)

Jej słabość, podkreślona szeregowo wymienionymi epitetami (drobne, chude, delikatne, prawie przezroczyste; rzadkie, drobne, powolne, objawiajace śmiertelnq obawę), wyklucza obowiązki matki, toteż wychowanie dzieci, ich wzrastanie odbywa się poza Emilią, niejako w atmosferze jej macierzyńskiej nieobecności. Nawet wówczas, gdy Witolda i Leonię w swoim życiu dostrzega, mówi tylko o sobie, jak tuż przed ich powrotem do domu: „Tak, doprawdy, osłabiona dziś jestem [...], że nie wiem, czy zdołam wyjść na spotkanie moich dzieci” (56). Emilia na swój sposób kocha dzieci, szczególnie pierworodnego Witolda, którego wcześniej, w dzieciństwie ,pieściła więcej jak córkę” (574) i z którego, gdy dorósł - jako że smukły i delikatny i „w rozrzewniający sposób” (574) przypomina dawnego Benedykta - jest dumna. Bardziej jednak żyjąca w świecie ułudy dba o pozory, a szczególnie o wygląd swej córki, która nie może być ,gorzej ubrana od [panien - E.S.R.] Darzeckich...” (282). Zagrożeniem dla wyznawanych przez Emilię zasad jest proponowane przez Witolda wspólne z nim wyjście Leonii na wesele w zaścianku:

$J a[\ldots]$ na takie dziwactwa zgodzić się nie mogę... Bardzo mi smutno, Widziu, że odmówić ci muszę, ale matka jestem i prowadzenie Leonii jest moim świętym obowiazkiem... Kiedy złożycie mię do mogity, będziecie z nią postępować, jak się wam będzie podobało, ale dopóki ja żyję, moja córka nie będzie bywać w niewłaściwych dla siebie towarzystwach, psuć sobie układu i patrzeć na rzeczy, których nigdy widzieć nie powinna. (573)

Nasycenie wypowiedzi wzniosłymi w treści frazeologizmami (jestem mat$k a$, święty obowiazek, złożyć do mogiły) nadaje jej patosu sytuującego oświadczenie matki u granicy tragedii, której ma Emilia zapobiec jak romantyczna heroina. Podjętą przez nią walkę i jej bohaterstwo podkreślają zaimki: ja, moim, mię, moja.

Wierzbowa matka. W polszczyźnie gwarowej frazeologizmem wierzbowy ojciec określano dawniej mężczyznę ${ }^{31}$, który cudze dziecko za swoje

${ }^{31}$ Szerzej w: E. Skorupska-Raczyńska, Motywy dendrologiczne w historii frazeologii i paremiologii polskiej, „Studia Językoznawcze” 2005, t. 4, s. 305-317. 
przyjmie i wychowa. Przywołany we frazeologizmie komponent wierzbowy konotuje właściwości wegetacyjne wierzby, jej dużą witalność oraz łatwość asymilacji w naturze, a to wskazuje na cechy, jakie ma człowiek określany mianem wierzbowy ojciec. Zwyczajowo kolejnego męża matki (w stosunku do jej potomstwa z poprzedniego małżeństwa) nazywamy ojczymem, zaś kolejną żonę ojca w podobnej relacji - macochą ${ }^{32}$. Oba terminy charakteryzują się, w przeciwieństwie do wyrażenia wierzbowy ojciec, mniejszym bądź większym nacechowaniem pejoratywnym. Wierzbową matką moglibyśmy nazwać kobietę, która cudze dziecko za swoje przyjmie i wychowa. W Nad Niemnem rolę wierzbowej matki odgrywa Marta Korczyńska, która przejmuje macierzyńskie zadania Emilii i jej dzieci kocha i chowa jak własne, dając im matkę swą osoba. Podkreśla to Benedykt, odpowiadając Marcie na propozycję jej odejścia razem z Justyną do Bohatyrowicz:

A cóż ja bym był począł, gdybym ciebie przy sobie nie miał? [...] Kobieta uczciwa, pracowita, rządna, życzliwa w domu i gospodarstwie - bagatela! [...] Ależ ty dzieci moje na rękach swych wynositaś $i$ wyhodowataś! Ty je jak matka i... za matkę... kochałaś i pieściłaś, a nie po głupiemu pieściłaś! Witold wiele ci winien, bo dobre, ludzkie rzeczy w glowę mu kładtaś... (763)

Marta kocha oboje mądrą miłością, pełną czułości i troski. Przyjazd Widzia i Leonii napawa kobietę ogromną radością. Widząc zbliżający się ku bramie Korczyna pojazd, stojąca tuż za Benedyktem Marta wzruszona i rozradowana szeptała: „Aniołki! kotki! robaczki moje!” (56). Do obojga też bezpośrednio zwracała się, używając pieszczotliwych określeń, takich jak: kotku ty mój, robaczku, mój maleńki, złoty, mily (do Witolda) i kotko ty moja, robaczku, stowiczku, rybko (do Leonii). Pełnię uczuć Marty wobec chłopca i dziewczynki oddają opisy, np. zabawy całej trójki w domowej spiżarni, w której kobieta chciała się zamknąć podczas wizyty lekarza we dworze, proszona wcześniej przez dzieci, by zezwoliła mu siebie zbadać.

Marta odwróciła się i wątłą dziewczynkę nad ziemię unióstszy namiętnymi pocatunkami jej włosy, oczy i usta okryła. Zarazem do wnętrza spiżarni ją wciagnęła, prawie wniosła, za sobą i za nią drzwi trzaskiem na klucz zamykając. Dopadł do nich teraz i Witold. [...] Ale we wnętrzu spiżarni słychać było wiele naraz odgłosów: śmiech, całusy, brzqkanie szklanych naczyń. Widocznie $w$ fortecy tej bawiono się wybornie. [...] Po chwili wszyscy troje znajdowali się w spiżami. Ileż chwil, odkąd tylko pamięcią sięgnąc mogli, przepędzili oni w tym miejscu z tą wielką, gderliwą i często szyderską kobieta, która ich tu całowała, na ręku swym nosiła,

${ }^{32}$ Por. USJP 2, s. 524, 1219. Tam również językowa ilustracja stereotypu. 
przysmakami najrozmaitszymi karmiła, czasem tak pasła, że aż potem chorowali, a ona doglądała ich znowu, leczyła, drżqc o nich tak, że aż goraczkowe rumieńce żótte policzki jej pality, a do snu i dla rozrywki śpiewajac im grubym swym głosem te stare pieśni, które z dala od dworu unosiły się nad polami. (277)

Witold i Leonia odwzajemniali uczucia ciotki i kochali ją równie mocno jak ojca, co już widać było po ich powrocie, podczas powitania w Korczynie, kiedy to „każdy by odgadł, że ci, których witać miano, rzucq się naprzód w objęcia tych dwojga ludzi" (56). Oboje też lękali się o ciotkę, o jej zdrowie, i prosili, by zechciała się leczyć. Leonia, by ciotkę obłaskawić, przynosi jej własnoręcznie wykonany prezent, co rozczula kobietę do łez:

Pantofle własnej roboty kochanej cioci ofiarowuję i proszę je przyjąć. [...] Miała widać coś bardzo długiego i pięknego wypowiedzieć, ale widząc twarz Marty tak drgającą [...] nie dokończyła, tylko z podskokiem na szyję starej panny szczupłe ramiona zarzuciła i mała, ciemna, pomarszczona, drgajaca twarz pocałunkami okrywała. Rzecz była drobną, a jednak Marta śmiała się i razem płakała, dziewczynkę nad ziemią unosząc, do piersi ją przyciskając i w nieskończoność szepczq̨c, wykrzykujac $i$ wykaszlujac. [...] Przyglądała się potem pantoflom, [...] przymierzała z uszczęśliwieniem, które dziwne w niej sprowadzało zmiany: młodsza jakby, lizejsza, cichszaja czyniqc. (570-571)

Zestawienie w kreacji Marty kontrastowych epitetów - ciemna, pomarszczona, drgajaca \| młodsza, lizejsza, cichsza - podkreśla rangę relacji dzieci z ciotką i ich wpływ na jej życie.

Marta jest typem matki wierzbowej, kochającej dzieci Benedykta, jak dobra matka własne, i przez nie kochanej. Obdziela je instynktownie miłością mądra, wychowuje, uczy, bawi, karmi, dogadza, tuli do snu, strzeże, podczas ich nieobecności - tęskni, by płakać z radości, gdy wracają. W pewnym zakresie zastępuje matkę również Justynie, mimo że jest dla niej tylko ubogą krewną, ciotka.

\section{Tytułem podsumowania}

Wykreowany w epopei Nad Niemnem wizerunek matki jest niejednolity, a analiza treści utworu pozwala na wskazanie kilku różnych jej typów.

Oddana dzieciom mądrze i gotowa zrobić dla nich wszystko, co służy racjonalnie ich dobru, jest Maria Kirłowa, która jak Matka Polka prowadzi samodzielnie gospodarstwo, jest strażniczką domowego ogniska, samotnie wychowuje dzieci do życia w społeczeństwie drugiej połowy XIX wieku. 
Kolejna matka, Andrzejowa Korczyńska, dumna patriotka, tworzy postać pomnikową. Żyjąca ideałami wdowa jest - jak może się wydawać - kobietą do naśladowania, ale wyalienowana środowiskowo ponosi porażkę, na którą swymi decyzjami dotyczącymi Zygmunta przez wiele lat intensywnie pracowała. Syn wykorzystuje ją, wiedząc, że matka zrobi dla niego wszystko jak matka kotka, byle był genialny, zadowolony i szczęśliwy.

Jeszcze innym typem matki wykreowanym przez Orzeszkową jest Starzyńska - matka kukułka, która swe dzieci podrzuca na wychowanie: Anzelmowi - Janka, a potem Jankowi - Antolkę. Przyczyną jest silniejsza od uczuć macierzyńskich potrzeba kolejnego zamążpójścia. Mimo że jako matka w pewien sposób uczestniczy w życiu swych dzieci, nie doświadcza z ich strony rodzinnych więzi emocjonalnych.

Matką zaoczna, czyli nieobecną w procesie rozwoju dzieci, jest skupiona na sobie Emilia. Swe role macierzyńskie ogranicza ona w zasadzie do dbałości o pozory i preferowane przez nią role społeczne. Rolę matki Witolda i Leonii przejmuje za Emilię Marta, która - jak wierzbowa matka - wychowuje je, karmi, uczy, pociesza, rozpieszcza, ale wymaga, troszczy się, a przede wszystkim jest zawsze i dla nich.

W skomplikowanej rzeczywistości drugiej połowy XIX wieku pozycja kobiet polskich była dość trudna, również w zakresie pełnionych obowiązków macierzyńskich, postrzeganych i realizowanych przez matki bardzo różnie, czego wymowne odzwierciedlenie odnajdujemy w realistycznej powieści Nad Niemnem Elizy Orzeszkowej.

\section{Elżbieta Skorupska-Raczyńska}

\section{The linguistic creation of the mother's representation in Eliza Orzeszkowa's Nad Niemnem}

A content analysis of the E. Orzeszkowa's Positivist novel Nad Niemnem [On the Niemen] makes it possible to indicate a number of different mother-types featured in the book and created by its author, namely: the Polish Mother, the caring cat mother, the cuckoo-type mother, the mother in absentia and the willow mother.

The type of the Polish Mother (an ideal of patriotic motherhood, Polish: Matka Polka, the Polish Mother was the secular equivalent of the Holy Mother) is epitomized in Maria Kirłowa, earnestly and wisely devoted to her children. She runs and manages the household single-handedly, is a guardian of the home, and all alone raises her children and prepares them to live in the society of the latter half of the nineteenth century. Another mother, Andrzejowa Korczyńska, a proud Polish patriot, makes a rather monumental figure. Living a life full of ideals and rich promises, this widow seems to provide a model of proper motherhood to be followed, but, being alienated in the 
family and her social environment, is eventually a failure and she fails in life. Her son takes advantage of her, knowing that she is ready to do everything for him no matter what happens, like a cat-mother. The mother-cuckoo is represented by Starzyńska, who chooses her personal interests over the importance of family and her children, Janek and Antolka, and lets somebody else raise them. The reason behind her behavior is the need for remarrying, apparently stronger than her maternal feelings. The mother in absentia, i.e. one that is virtually non-existent in the process of the education and development of her children, is self-concentrated and self-obsessed Emilia. In this particular case, the role of Witold and Leonia's mother is taken over by Marta, who - like a willow-mother - raises them, feeds them, educates, consoles and pampers them, not forgetting, however, about being a demanding and controlling guardian. Most of all, however, she is always there and is always ready to assist them.

The novel, set in the complicated reality of the challenging second half of the nineteenth century, is a moving reminder how restrictive women's standing was and how this situation influenced the woman's family duties as well. These responsibilities were viewed and executed by contemporary mothers differently and had a different meaning for them, which is very eloquently presented in Eliza Orzeszkowa's realistic novel.

KEY WORDs: linguistic creation, semantics, lexis.

prof. nadzw. dr hab. Elżbieta Skorupska-Raczyńska, Zakład Języka Polskiego, Instytut Humanistyczny Państwowej Wyższej Szkoły Zawodowej w Gorzowie Wielkopolskim, Katedra Języka i Komunikacji Religijnej, Wydział Teologiczny Uniwersytetu Szczecińskiego; zainteresowania badawcze: językoznawstwo kognitywne, leksykografia, semantyka tekstu, frazeologia i paremiologia oraz funkcja barw w języku. 